\title{
Properties and gene structure of a bifunctional cellulolytic enzyme (CelA) from the extreme thermophile 'Anaerocellum thermophilum' with separate glycosyl hydrolase family 9 and 48 catalytic domains
}

\author{
Vladimir Zverlov, ${ }^{1}+$ Sabine Mahr, ${ }^{2}$ Kathrin Riedel ${ }^{2}$ \\ and Karin Bronnenmeier ${ }^{2}$ \\ Author for correspondence: Karin Bronnenmeier. Tel: +49892892 2637. Fax: +498928922360. \\ e-mail : bronnen@biol.chemie.tu-muenchen.de
}

1 Institute of Molecular Genetics, Russian Academy of Science, Kurchatov Sq. 46, 123182 Moscow, Russia

2 Institute for Microbiology, Technical University Munich, Arcisstr. 21, D-80290 München, Germany

\begin{abstract}
A large cellulolytic enzyme (CelA) with the ability to hydrolyse microcrystalline cellulose was isolated from the extremely thermophilic, cellulolytic bacterium 'Anaerocellum thermophilum '. Full-length CelA and a truncated enzyme species designated CelA' were purified to homogeneity from culture supernatants. CelA has an apparent molecular mass of $230 \mathrm{kDa}$. The enzyme exhibited significant activity towards Avicel and was most active towards soluble substrates such as CM-cellulose (CMC) and $\beta$-glucan. Maximal activity was observed between $\mathrm{pH}$ values of 5 and 6 and temperatures of $95^{\circ} \mathrm{C}$ (CM-cellulase) and $85^{\circ} \mathrm{C}$ (Avicelase). Cellobiose, glucose and minor amounts of cellotriose were observed as end-products of Avicel degradation. The CelAencoding gene was isolated from genomic DNA of 'A. thermophilum' by PCR and the nucleotide sequence was determined. The celA gene encodes a protein of 1711 amino acids (190 kDa) starting with the sequence found at the $N$ terminus of CelA purified from 'A. thermophilum'. Sequence analysis revealed a multidomain structure consisting of two distinct catalytic domains homologous to glycosyl hydrolase families 9 and 48 and three domains homologous to family III cellulose-binding domain linked by Pro-Thr-Ser-rich regions. The enzyme is most closely related to CelA of Caldicellulosiruptor saccharolyticus (sequence identities of 96 and $97 \%$ were found for the $\mathbf{N}$ - and C-terminal catalytic domains, respectively). Endoglucanase CelZ of Clostridium stercorarium shows $70.4 \%$ sequence identity to the $\mathbf{N}$-terminal family 9 domain and exoglucanase CelY from the same organism has $69 \cdot 2 \%$ amino acid identity with the C-terminal family 48 domain. Consistent with this similarity on the primary structure level, the $90 \mathrm{kDa}$ truncated derivative CelA' containing the $\mathrm{N}$-terminal half of CelA exhibited endoglucanase activity and bound to microcrystalline cellulose. Due to the significantly enhanced Avicelase activity of full-length CelA, exoglucanase activity may be ascribed to the C-terminal family $\mathbf{4 8}$ catalytic domain.
\end{abstract}

Keywords: 'Anaerocellum thermophilum', cellulase, endo-1,4- $\beta$-glucanase, exo-1,4- $\beta$ glucanase, thermostability
†Present address: Institute for Microbiology, Technical University Munich, Arcisstr. 21, D-80290 München, Germany.

Abbreviations: $\mathrm{CMC}$, CM-cellulose; CMCase, CM-cellulase.

The GenBank accession number for the nucleotide sequence reported in this paper is Z86105.

\section{INTRODUCTION}

'Anaerocellum thermophilum' is an extremely thermophilic, obligately anaerobic, chemoorganotrophic bacterium which was isolated from a hot spring with residues of higher plants in the Valley of Geysers on the 
Kamchatka peninsula, Russia (Svetlichnyi et al., 1990). It utilizes a wide spectrum of polymeric carbohydrates and sugars. The preferred substrate is cellulose, which is quite rapidly and efficiently metabolized. Phylogenetic analysis revealed that 'A. thermophilum' strain Z-1320 is closely related to strain Tp8T6331 isolated from New Zealand thermal springs which was tentatively named 'Caldocellum saccharolyticum' and has now been designated Caldicellulosiruptor saccharolyticus (Rainey et al., 1994). The phylogenetic position of both strains as a novel lineage within the Bacillus/Clostridium subphylum of the Gram-positive bacteria has recently been reported (Rainey et al., 1993).

To use cellulose or hemicellulose as sources of carbon and energy, micro-organisms produce a repertoire of hydrolytic enzymes, with various specificities, which act cooperatively to convert these substrates to their constituent sugars (Warren, 1996). These enzymes commonly show a modular organization and consist of a single catalytic domain linked to one or more non-catalytic domains. However, bifunctional polysaccharidases composed of two dissimilar catalytic domains joined by linker regions have been identified via gene cloning in Ruminococcus flavefaciens (Zhang \& Flint, 1992; Flint et al., 1993), Clostridium thermocellum (Ahsan et al., 1996) and Ca. saccharolyticus. In the latter organism, a cellulase-hemicellulase gene cluster composed of the genes celA (Te'o et al., 1995), celB (Saul et al., 1990), manA (Gibbs et al., 1992) and celC (Morris et al., 1995) has been characterized.

In this paper, we describe purification and characterization of the predominant cellulolytic enzyme produced by 'A. thermophilum' and show that this large enzyme, which contains two separate catalytic regions within the same polypeptide, is encoded by a single gene.

\section{METHODS}

Bacterial strains, plasmids and growth conditions. 'A. thermophilum' Z-1320 (Svetlichnyi et al., 1990) was obtained from the Laboratory of Lithotrophic Microorganisms at the Institute for Microbiology, RAS, Moscow, Russia. Cells were grown at $70^{\circ} \mathrm{C}$ and $\mathrm{pH} 6.7$ in a 71 fermenter under anaerobic conditions in CM5 medium (Weimer et al., 1984) supplemented with $0.2 \%$ yeast extract and $0.3 \%$ tryptone. Cellobiose $(0.4 \%)$ was added as carbon source.

The cloning vector/host strain combinations used for cloning and sequencing were pGEM-T (Promega) or pUC18/ Escherichia coli DH5 $\alpha$ (Hanahan, 1983; Yanisch-Perron et al., 1985). Recombinant E. coli cells were grown at $37^{\circ} \mathrm{C}$ in Luria-Bertani broth containing $100 \mu \mathrm{g}$ ampicillin $\mathrm{ml}^{-1}$.

Purification of CelA and CelA' from 'A. thermophilum'. Culture supernatant $(20 \mathrm{l})$ was concentrated by ultrafiltration employing a Minisette tangential flow system (Filtron) equipped with Nova filters with a nominal molecular mass limit of $30000 \mathrm{Da}$. The retentate $(660 \mathrm{ml})$ was desalted by five cycles of ultrafiltration following a twofold dilution with $20 \mathrm{mM}$ Tris/ $\mathrm{HCl}, \mathrm{pH} 8 \cdot 0$. The chromatographic steps of the purification were performed with a Pharmacia FPLC system.
The crude exoenzyme preparation (507 $\mathrm{mg}$ protein) was loaded on a Pharmacia XK 26/20 column filled with $32 \mathrm{ml} \mathrm{Q}$ Sepharose Fast Flow which had been equilibrated with $20 \mathrm{mM}$ Tris $/ \mathrm{HCl}, \mathrm{pH} 8 \cdot 0$. Fractions in the flow-through were pooled, adjusted with $1.2 \mathrm{M}$ ammonium sulfate and applied to a Pharmacia Phenyl Sepharose HP HiLoad 16/10 hydrophobic interaction column equilibrated with $20 \mathrm{mM}$ Tris/ $\mathrm{HCl}, 1.2 \mathrm{M}$ ammonium sulfate, $\mathrm{pH} 8.0$. Elution was performed with a $420 \mathrm{ml}$ linear gradient $(1 \cdot 2-0.0 \mathrm{M}$ ammonium sulfate) in $20 \mathrm{mM}$ Tris $/ \mathrm{HCl}(\mathrm{pH} 8.0)$ at a flow rate of $2 \mathrm{ml} \mathrm{min}^{-1}$. Two peaks exhibiting Avicelase as well as CM-cellulase (CMCase) activity were eluted. The CelA-containing fractions of the peak eluted at the end of the salt gradient were pooled and concentrated in a Macrosep centrifugal microconcentrator (Filtron). The concentrate $(2.5 \mathrm{ml})$ was applied to a Pharmacia Superdex 200 prep-grade HiLoad 16/60 gel filtration column equilibrated with $100 \mathrm{mM}$ sodium succinate $(\mathrm{pH} 6.0)$ containing $1 \mathrm{M} \mathrm{NaCl}$. The column was eluted at a flow rate of $1 \mathrm{ml} \mathrm{min}-1$ with equilibration buffer. Two repeat runs were performed.

The CelA'-containing fractions of the peak eluted at $0.3 \mathrm{M}$ ammonium sulfate from the Phenyl Sepharose column described above were subjected to chromatofocusing on a Pharmacia Mono P HR 5/20 column equilibrated with $75 \mathrm{mM}$ Tris/ $\mathrm{HCl}, \mathrm{pH} 9 \cdot 5$. The column was eluted with $50 \mathrm{ml}$ Pharmacia Polybuffer 96, diluted $1: 10$ and adjusted to $\mathrm{pH} 7 \cdot 0$ at a flow rate of $1 \mathrm{ml} \mathrm{min}^{-1}$. Fractions eluting at a $\mathrm{pH}$ of 8.65 were applied to a Pharmacia HR 5/5 column filled with POROS Self Pack 20 ET (PerSeptive Biosystems) and equilibrated with $50 \mathrm{mM}$ sodium phosphate buffer, $1.2 \mathrm{M}$ ammonium sulfate, $\mathrm{pH} 7 \cdot 0$. Elution was performed with a $15 \mathrm{ml}$ linear gradient $(1.2-0.0 \mathrm{M}$ ammonium sulfate) in $50 \mathrm{mM}$ sodium phosphate $(\mathrm{pH} 7 \cdot 0)$ at a flow rate of $10 \mathrm{ml} \mathrm{min}^{-1}$.

Enzyme assays. Enzyme assays were done at $72{ }^{\circ} \mathrm{C}$ in 0.5 or $0.75 \mathrm{ml}$ reaction mixtures containing $0.1 \mathrm{M}$ sodium succinate ( $\mathrm{pH} 6.0$ ) and either $0.5 \%(\mathrm{w} / \mathrm{v})$ soluble polysaccharide substrates or $1 \%(\mathrm{w} / \mathrm{v})$ non-soluble substrates. The enzymic liberation of reducing groups was determined with the dinitrosalicylic acid reagent (Wood \& Bhat, 1988). One unit of enzyme activity was defined as the amount of enzyme needed to release $1 \mu \mathrm{mol}$ glucose-equivalent reducing groups $\mathrm{min}^{-1}$.

CM-cellulose (CMC; low viscosity) was purchased from Sigma. Avicel (microcrystalline cellulose $0.02 \mathrm{~mm}$ ) was from Serva. Oat spelts xylan was from Fluka. Barley $\beta$-glucan was from Megazyme. Acid-swollen Avicel was prepared by incubating Avicel in concentrated $\mathrm{HCl}$ with continuous agitation for $2 \mathrm{~h}$ (Sakamoto et al., 1984).

Analytical methods. Protein concentrations were measured by the method of Sedmak \& Grossberg (1977). SDS-PAGE was performed in $7.5 \%$ polyacrylamide slab gels in the presence of $0.1 \%$ SDS according to Laemmli (1970). CMCase and $\beta$ glucanase bands were visualized by a modification of the zymogram technique described by Schwarz et al. (1987): gels were incubated in $1 \% \mathrm{CMC}$ or $\beta$-glucan solutions instead of incorporation of these substrates into the polyacrylamide gels. Avicelase bands were detected by the filter paper affinity blotting technique of Montgomery \& Fu (1988). Cellulosebinding studies were performed as described by Hall et al. (1995). Protein glycosylation was analysed with the GlykoTrack kit (Oxford GlykoSystems). N-terminal amino acid sequences were determined by Edman degradation using a gas-phase amino acid Sequenator model 477A (Applied Biosystems). Cellodextrins were analysed by HPLC at $85^{\circ} \mathrm{C}$ on an Animex HPX-42 A column (Bio-Rad) with water as eluent. 
Table 1. Nucleotide sequences of PCR primers and biotinylated oligonucleotides

For oligonucleotides with mixed bases (wobbles) the following letters were used: $w$ represents $a / t$; $\mathrm{y}, \mathrm{c} / \mathrm{t} ; \mathrm{s}, \mathrm{g} / \mathrm{c} ; \mathrm{r}, \mathrm{a} / \mathrm{g} ;$ and $\mathrm{n}, \mathrm{a} / \mathrm{g} / \mathrm{c} / \mathrm{t}$.

\begin{tabular}{|c|c|c|}
\hline Primer & Sequence & $\begin{array}{l}\text { Annealing } \\
\text { temp. }\left({ }^{\circ} \mathrm{C}\right)\end{array}$ \\
\hline$A \operatorname{Pr} 1$ & $5^{\prime}$-ggnwsnttyaaytayggngargcnytncaraa- $3^{\prime}$ & 50 \\
\hline $\operatorname{APr} 2 c$ & $5^{\prime}$-gcrttrtartcrcangcnac- $3^{\prime}$ & 50 \\
\hline $\operatorname{APr} 3$ & $5^{\prime}$-actgctcatagctcatgggca- $3^{\prime}$ & 58 \\
\hline $\operatorname{APr} 5(\mathrm{SalI})$ & $5^{\prime}$-ggagatgtgaaggtatgggtcgacggaccag-3' & 62 \\
\hline $\operatorname{APr} 6(\mathrm{Bam} \mathrm{HI})$ & $5^{\prime}$-gtatcttgttccataaccacaggatcctctgccc- $3^{\prime}$ & 62 \\
\hline $\operatorname{APr} 7$ & $5^{\prime}$-ggctggaggaacggggta $-3^{\prime}$ & 55 \\
\hline Oligonucleotide & & $\begin{array}{c}\text { Hybridization } \\
\text { temp. }\left({ }^{\circ} \mathrm{C}\right)\end{array}$ \\
\hline APr4-Bio & $5^{\prime}$-tatggagcgcttgttggtgg- $3^{\prime}$ & 55 \\
\hline APr8-Bio & $5^{\prime}$-gctatcatggtattatgcatgg- $3^{\prime}$ & 55 \\
\hline
\end{tabular}

Recombinant DNA techniques, sequencing and PCR. Preparation of chromosomal and plasmid DNA, endonuclease digestion, ligation, transformation and Southern hybridization analysis were carried out using standard procedures (Sambrook et al., 1989). Digoxigenin labelling was performed with the DIG DNA Labeling and Detection kit (Boehringer Mannheim). Enzymes for DNA modification were purchased from Boehringer Mannheim. The DNA sequence was determined from supercoiled double-stranded plasmid DNA by cycle sequencing of both strands (Amersham Thermosequenase Cycle Sequencing kit) with biotinylated primers. DNA fragments were detected with GATC 1500 DirectBlotting Electrophoresis apparatus using streptavidinconjugated alkaline phosphatase and nitro blue tetrazolium-5bromo-4-chloro-3-indolyl phosphate as chromogenic substrate (TROPIX). Sequence data were analysed and compared with the DNASIS/PRosis for Windows package (Hitachi Software Engineering). Nucleotide and protein sequence databases were screened using the BLAST software at the NCBI server (http://www.ncbi.nlm.nih.gov).

PCR was carried out using the synthetic oligonucleotide primers $A \operatorname{Pr} 1, A \operatorname{Pr} 2 c, A \operatorname{Pr} 3, A \operatorname{Pr} 5(\operatorname{Sall}), \operatorname{APr} 6(\operatorname{Bam} \mathrm{HI})$ and APr 7 (Table 1 and Fig. 4) with chromosomal DNA from ' $A$. thermophilum' as a template and an Expand High Fidelity PCR system (Boehringer Mannheim) used according to the supplier's protocol. In asymmetric PCR (L. Richter \& W. Ludwig, unpublished), only one primer is used which binds specifically to one DNA strand; the complementary strand is synthesized by unspecific binding, analogous to the random primer method. The template strands were separated at $94^{\circ} \mathrm{C}$ $(2 \mathrm{~min})$ before starting 30 reaction cycles $\left(94^{\circ} \mathrm{C} / 15 \mathrm{~s}, 50-\right.$ $62{ }^{\circ} \mathrm{C} / 30 \mathrm{~s}, 72^{\circ} \mathrm{C} / 2 \mathrm{~min}$ plus elongation of $10 \mathrm{~s}$ for each cycle). For asymmetric PCR, $0.75 \mu \mathrm{l}$ of the Expand High Fidelity PCR system enzyme mix was added to the reaction mixture after 30 reaction cycles and the cycle profile was repeated.

\section{RESULTS}

\section{Enzyme purification}

Culture supernatants of ' $A$. thermophilum' grown on cellobiose exhibited CMCase, $\beta$-glucanase and Avicelase activities. SDS-PAGE analysis of crude exoenzyme preparations revealed a prominent protein band with a molecular mass of approximately $230 \mathrm{kDa}$ (Fig. 1). This protein band was shown to exhibit CMCase and $\beta$ glucanase activities by in situ activity staining. Affinity binding to filter paper was taken as evidence for Avicelase activity. Purification of the $230 \mathrm{kDa}$ enzyme confirmed the notion that all three activities reside in the same protein (Fig. 1). As summarized in Table 2, a fivefold purification by FPLC chromatographic methods was sufficient to yield a homogeneous protein (Fig. 1). This implies that the large cellulolytic enzyme, later identified as CelA, constitutes at least $20 \%$ of the total extracellular protein produced by cellobiose-grown 'A. thermophilum'.

During hydrophobic interaction chromatography on Phenyl Sepharose, a $90 \mathrm{kDa}$ enzyme exhibiting CMCase activity was separated from the $230 \mathrm{kDa}$ cellulase. The $90 \mathrm{kDa}$ enzyme could be purified to electrophoretic homogeneity by chromatofocusing on a Mono P column and hydrophobic interaction chromatography on a POROS ET column (Fig. 2). Based on the molecular mass, substrate specificity (Table 3 ) and N-terminal amino acid sequence (Fig. 3), the $90 \mathrm{kDa}$ enzyme species was thought to have arisen from limited proteolysis of the CelA cellulase. This truncated derivative consisting of the N-terminal half of CelA was designated CelA'. Like the intact protein, CelA ${ }^{\prime}$ was able to bind to microcrystalline cellulose (data not shown).

\section{$\mathrm{N}$-terminal amino acid sequence}

$\mathrm{N}$-terminal sequencing of the $230 \mathrm{kDa}$ cellulase purified from 'A. thermophilum' by Edman degradation yielded the sequence GSFNYGEALQKAIMFYEFQMSGK for the first 23 amino acids. This sequence is found at positions 24 through 46 of the primary structure deduced 


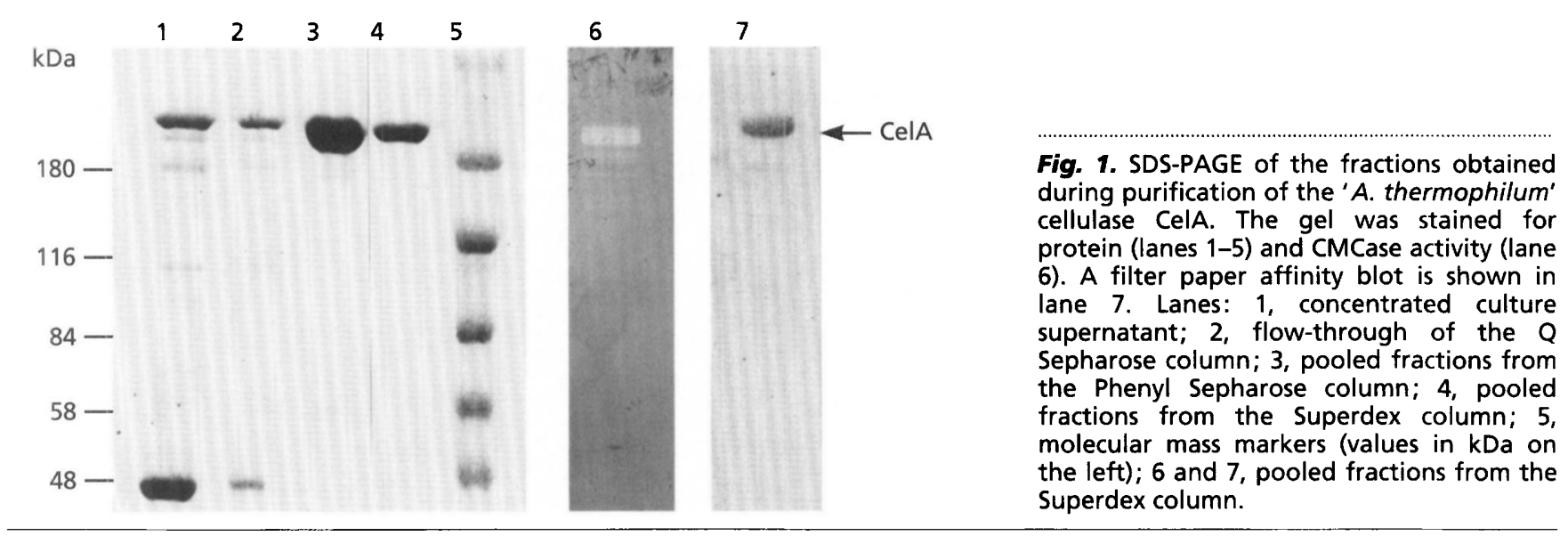

Table 2. Purification of ' $A$. thermophilum' cellulase from concentrated culture supernatant

Activity was determined under standard assay conditions at $72{ }^{\circ} \mathrm{C}$ with Avicel as the substrate.

\begin{tabular}{|lcccccc|}
\hline Purification step & $\begin{array}{c}\text { Volume } \\
(\mathbf{m l})\end{array}$ & $\begin{array}{c}\text { Protein } \\
(\mathbf{m g})\end{array}$ & $\begin{array}{c}\text { Activity } \\
(\mathbf{U})\end{array}$ & $\begin{array}{c}\text { Specific activity } \\
\left(\mathbf{m U ~ m g}^{-1}\right)\end{array}$ & $\begin{array}{c}\text { Purification } \\
(- \text {-fold })\end{array}$ & $\begin{array}{c}\text { Yield } \\
(\%)\end{array}$ \\
\hline $\begin{array}{l}\text { Culture supernatant } \\
\text { Ultrafiltration }\end{array}$ & 2000 & 810 & 45 & 60 & $1 \cdot 0$ & 100 \\
$\quad \begin{array}{l}\text { concentrate } \\
\text { Q Sepharose }\end{array}$ & 660 & 507 & 33 & 65 & $1 \cdot 1$ & 73 \\
Phenyl Sepharose & 750 & 248 & 19 & 77 & $1 \cdot 3$ & 42 \\
Superdex & 46 & 45 & 7 & 156 & $2 \cdot 6$ & 16 \\
& 10 & 14 & 4 & 285 & $4 \cdot 8$ & 9 \\
\hline
\end{tabular}

from the nucleotide sequence of the $\mathrm{cel} A$ gene of $\mathrm{Ca}$. saccharolyticus (Te'o et al., 1995; GenBank accession no. L32742). The signal peptidase cleavage site of the Ca. saccharolyticus CelA protein was predicted to lie between residues 20 and 21 or 23 and 24 , respectively. Thus, the mature proteins from 'A. thermophilum' and Ca. saccharolyticus show identical sequences at their $\mathrm{N}$ termini. Since the N-terminal catalytic domain of CelA from $\mathrm{Ca}$. saccharolyticus belongs to glycosyl hydrolase family 9, CelA from 'A. thermophilum' was also thought to be a member of this family. Accordingly, other family 9 cellulases, such as CelZ of Clostridium stercorarium (Jauris et al., 1990; GenBank accession no. X55299) and CelI of Cl. thermocellum (Hazlewood et al., 1993; GenBank accession no. L04735), are also highly homologous at their $\mathrm{N}$-termini with the $\mathrm{N}$ terminal sequence determined for ' $A$. thermophilum' CelA (Fig. 3).

\section{PCR cloning of the celA gene region}

The 5 ' region of the celA gene was amplified from ' $A$. thermophilum' genomic DNA by PCR with two oligonucleotide primers. The first $11 \mathrm{~N}$-terminal amino acids provided sufficient information to deduce the sequence of the forward primer APr1 (Table 1 and Fig. 4). The reverse primer $\operatorname{APr} 2 c$ (Table 1 and Fig. 4) was derived from the complementary nucleotide sequence deduced from a conserved sequence region identified in the family 9 cellulases CelA of Ca. saccharolyticus, CelZ of $\mathrm{Cl}$. stercorarium and CelI of $\mathrm{Cl}$. thermocellum (Fig. 3). The $1.3 \mathrm{~kb}$ PCR products from two independent reactions were cloned into the $E$. coli vector pGEM-T. The DNA inserts from plasmids pATP1 and pATP2 isolated from two different recombinant clones were sequenced and had the same nucleotide sequence, thus eliminating the possibility of errors being introduced during PCR amplification.

Cloning of the missing part of the celA gene was achieved by two asymmetric PCR reactions using the single primers $A \operatorname{Pr} 3$ and $A \operatorname{Pr} 7$ (Table 1 and Fig. 4). The amplified DNA fragments were screened with biotinylated oligonucleotide probes (APr4-Bio and APr8-Bio; Table 1 and Fig. 4) by Southern hybridization. PCR products of $1 \cdot 1,1.8$ and $2 \cdot 3 \mathrm{~kb}$ were selected from the reaction with primer $A P r 3$ and a $1.5 \mathrm{~kb}$ product was selected from the reaction with primer $A P r 7$. These fragments were cloned into vector pGEM-T and the resulting plasmids were designated pATP3-1, pATP3-2, pATP3-3 and pATP7, respectively (Fig. 4). DNA sequencing revealed that pATP3-2 and pATP3-3 had lost part of their DNA inserts, probably as a result of recombination events. The gap was filled by PCR with the two primers $\operatorname{APr} 5(\operatorname{SalI})$ and $A \operatorname{Pr} 6(B a m \mathrm{HI})$ containing recognition sites for SalI and BamHI, which were used for cloning of the resulting PCR fragment into 


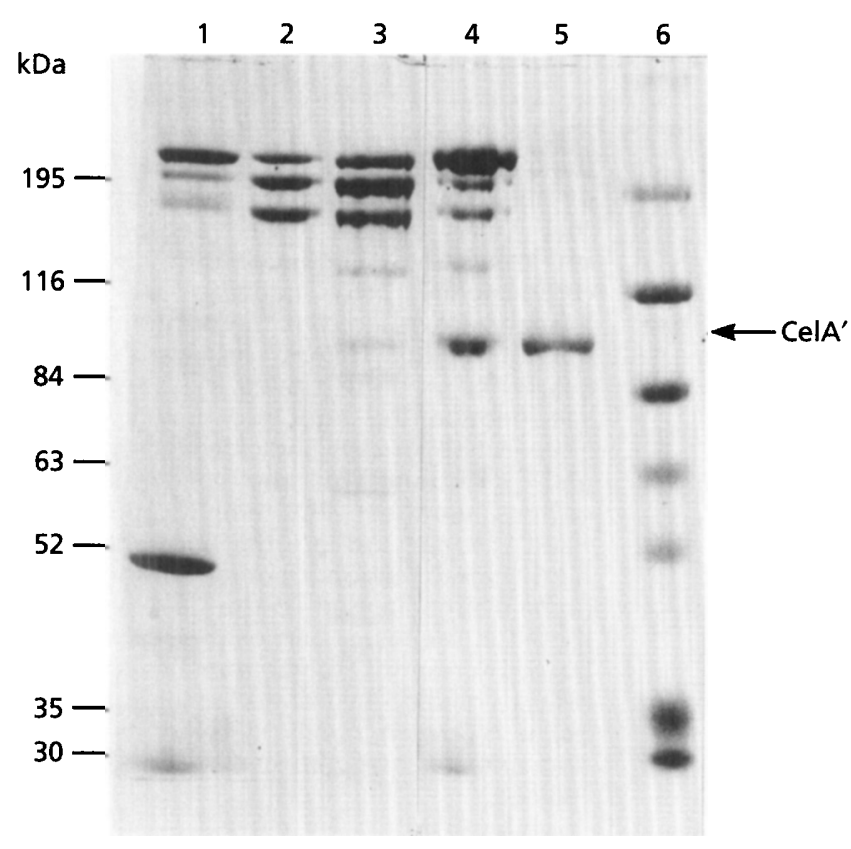

Fig. 2. SDS-PAGE of the fractions obtained during purification of the truncated cellulase CelA'. Lanes: 1 , concentrated culture supernatant; 2, flow-through of the Q Sepharose column; 3, pooled fractions from the Phenyl Sepharose column; 4, pooled fractions of the Mono $P$ column; 5, pooled fractions of the POROS $20 \mathrm{ET}$ column; 6 , molecular mass markers (values in $\mathrm{kDa}$ on the left).

Table 3. Substrate specificity of the 'A. thermophilum' cellulase

Standard assays were performed at $72{ }^{\circ} \mathrm{C}$ using CelA concentrations of $7.4 \mathrm{ng} \mathrm{ml}^{-1}$ or $74 \mathrm{pg} \mathrm{ml}^{-1}$ (in the case of $\beta$ glucan). CelA' concentrations were $7 \cdot 1 \mathrm{ng} \mathrm{ml}^{-1}$ or $71 \mathrm{pg} \mathrm{ml}^{-1}$ (in the case of $\beta$-glucan). Incubations were carried out for $15 \mathrm{~min}$ for $\mathrm{CMC}$ and $\beta$-glucan, $45 \mathrm{~min}$ for xylan and up to $5 \mathrm{~h}$ for Avicel. The results are the means of nine separate determinations in which values did not deviate by more than $15 \%$ of the mean.

\begin{tabular}{|lrr|}
\hline Substrate & \multicolumn{2}{c|}{ Activity $\left(\mathbf{m U ~ n m o l}^{\mathbf{- 1}}\right)$} \\
\cline { 2 - 3 } & \multicolumn{1}{c}{ CelA } & CelA $^{\prime}$ \\
\hline Avicel & 55 & 18 \\
Avicel, acid-swollen & 82 & 76 \\
CMC & 1758 & 1801 \\
$\beta$-Glucan (barley) & 100510 & 88244 \\
Xylan (oat spelts) & 372 & 123 \\
\hline
\end{tabular}

pUC18 yielding plasmid pATP5 (Fig. 4). In the cases of pATP5 and pATP7, the nucleotide sequences were again determined for two independent PCR clones.

\section{Nucleotide sequence analysis}

The origin and structural integrity of the sequenced $5.5 \mathrm{~kb}$ DNA fragment were checked with Southern blot (a)

\begin{tabular}{|c|c|}
\hline & 10 \\
\hline $\mathrm{h}-\mathrm{CelA}$ & GSFNYGEALQKAIMFYEFQMSGK \\
\hline elA' & GSFNYGEALQKAIMFYEFQMSGKL \\
\hline$a-\operatorname{Cel} A$ & GSFNYGEALQKAIMFYEFQMSGKL \\
\hline Cst-Celz & AGYNYGEALQKAIMFYEFQRSGKL \\
\hline Cth-CelI & GAFNYGEALQKAI FFYECQRSGKL \\
\hline
\end{tabular}

(b)

$\begin{array}{lccc} & 420 & 430 & 440 \\ \text { Ath-CelA } & \text { NEVACDYNAGFVGALAKMYQLYGG } \\ \text { Csa-CelA } & \text { NEVACDYNAGFVGALAKMYLLYGG } \\ \text { Cst-Celz } & \text { NEVACDYNAGFVGALAKMYEDYGG } \\ \text { Cth-CelI } & \text { NEVACDYNAGFVGLLAKMYKLYGG }\end{array}$

$------$

Fig. 3. N-terminal amino acid sequences (a) and highly conserved sequence regions (b) used for the design of PCR primers. CelA' represents the $90 \mathrm{kDa}$ truncated derivative of the CelA enzyme. Dissimilar amino acids are indicated by bold letters. The amino acid sequence regions used to deduce primer sequences are underlined. Ath, 'A. thermophilum'; Csa, Ca. saccharolyticus; Cst, Cl. stercorarium; Cth, Cl. thermocellum.

experiments. A digoxigenin-labelled HindIII-HindIII fragment from pATP1, a Nsil-Nsil fragment from pATP7 and an EcoRI-Nsil fragment from pATP3-3 were used to probe chromosomal DNA of ' $A$. thermophilum' digested with HindIII, NsiI, NsiI plus $H$ indIII, and NsiI plus EcoRI. The hybridization signals obtained were in full accordance with the anticipated results (data not shown).

The nucleotide sequence of a $5513 \mathrm{bp}$ fragment of ' $A$. thermophilum' chromosomal DNA has been deposited in the GenBank database (accession no. Z86105). Two open reading frames, ORF1 (5136 bp) and incomplete ORF2 (222 bp), separated by $156 \mathrm{bp}$, were found on the same strand. ORF1 is succeeded by a possible transcription terminator (nt 5156-5202) capable of forming a stem-loop structure with a calculated $\Delta G$ value of $-30 \cdot 2 \mathrm{kcal}(-126 \cdot 84 \mathrm{~kJ})$. Preceding the putative ATG initiation codon (nt 292-294) of ORF2, a potential ribosome-binding site (AGGGGGT, nt 5274-5280) and promoter-like -10 and -35 sequences (TAGTAC, nt 5247-5253; TATAAT, nt 5228-5232) were identified. Mean G $+C$ contents of 44.5 and $33.8 \mathrm{~mol} \%$ were determined for ORF1 and ORF2, respectively. For total genomic DNA of ' $A$. thermophilum' Z-1320, a G + C content of $36.7 \mathrm{~mol} \%$ has been reported (Svetlichnyi et al., 1990).

\section{Protein structure}

The protein translated from ORF1, later designated celA, has a predicted molecular mass of $190 \mathrm{kDa}$ and starts with the amino acid sequence obtained for the $\mathrm{N}$ terminus of CelA purified from ' $A$. thermophilum'. The discrepancy between the calculated molecular mass and the apparent molecular mass determined for the enzyme purified from 'A. thermophilum' by SDS-PAGE 


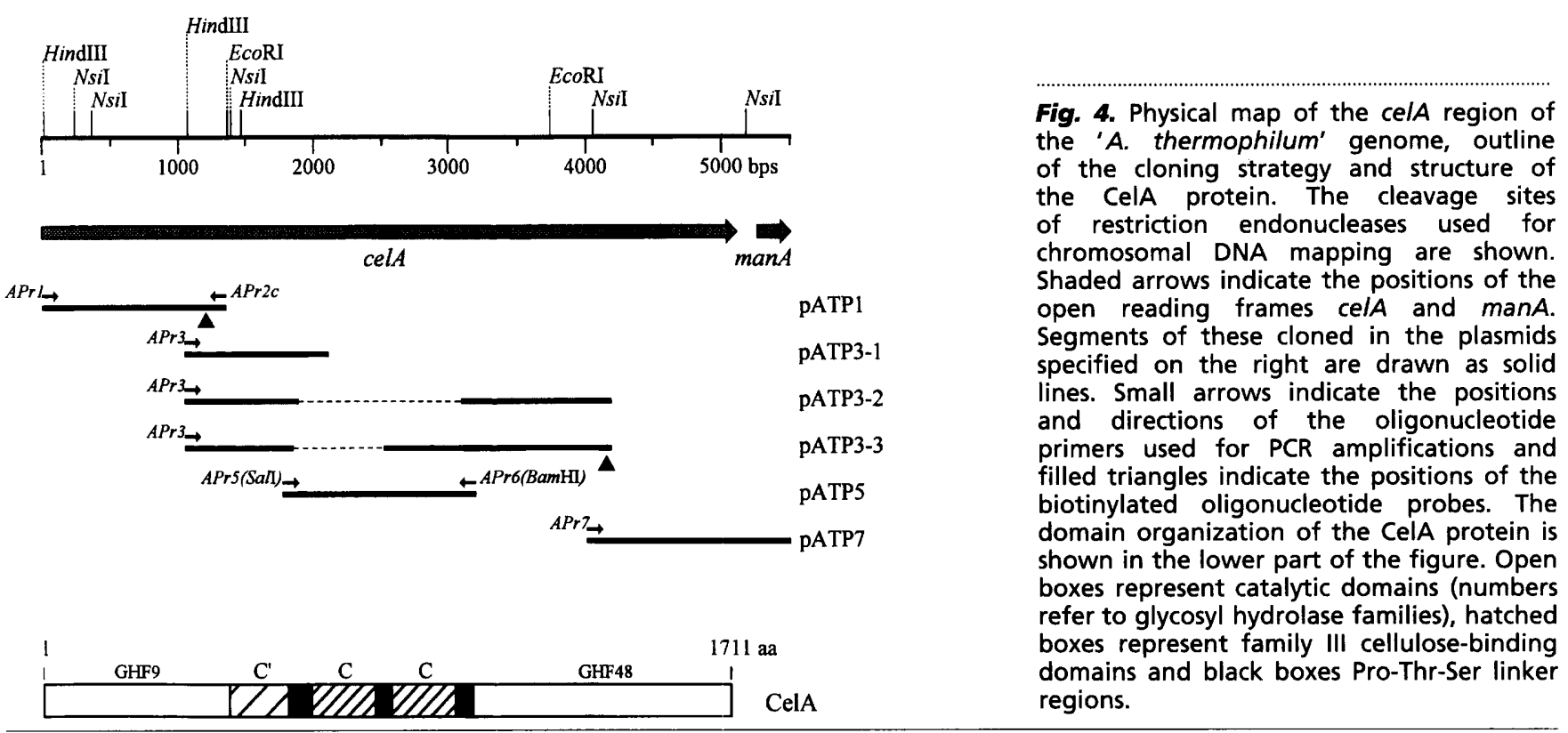

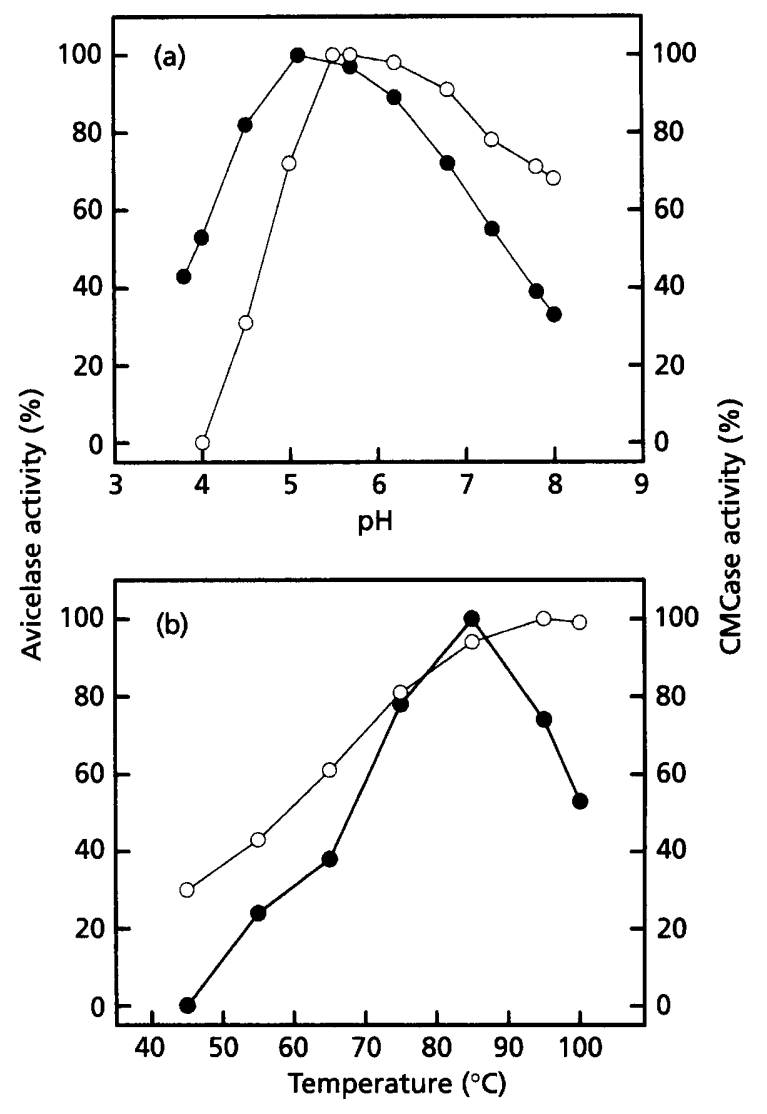

Fig. 5. Effect of $\mathrm{pH}$ and temperature on the activity of CelA from ' $A$. thermophilum'. Purified enzyme was incubated at various $\mathrm{pH}$ values (a) and temperatures (b) with the substrates Avicel (O) and CMC (O). Incubations were carried out for $60 \mathrm{~min}$ (Avicel) or $20 \mathrm{~min}$ (CMC) with $35 \mu \mathrm{g}$ (Avicel) or $1.4 \mu \mathrm{g}$ (CMC) purified enzyme. The buffers used were sodium succinate $(\mathrm{pH} 3 \cdot 8-6 \cdot 0)$ and sodium phosphate $(\mathrm{pH} 5 \cdot 0-8 \cdot 0)$.
$(230 \mathrm{kDa})$ is probably due to glycosylation of the native enzyme. CelA and CelA' blotted onto nitrocellulose both stained positively with a glycoprotein detection kit (not shown).

Further sequence analysis identified CelA from 'A. thermophilum' as a modular glycosyl hydrolase consisting of (i) two different catalytic domains belonging to glycosyl hydrolase families 9 and 48, (ii) three family III cellulose-binding domains (Béguin \& Aubert, 1994) showing homology to domains $C^{\prime}$ and $C$ found in CelY and CelZ of Cl. stercorarium (Bronnenmeier et al., 1997) and (iii) three Pro-Thr-Ser linker regions (Fig. 4).

The incomplete reading frame ORF2 encodes 74 amino acids of a protein with high similarity ( $90 \%$ identity) to the $\mathrm{N}$-terminal region of the $\beta$-mannanase from $C a$. saccharolyticus (Gibbs et al., 1992). ORF2 was therefore termed manA.

\section{Enzyme properties}

Characterization of the multidomain cellulase CelA was carried out with the native enzyme purified from ' $A$. thermophilum'. The influence of $\mathrm{pH}$ and temperature on enzyme activity was investigated for the substrates $\mathrm{CMC}$ and Avicel (Fig. 5). The $\mathrm{pH}$ and temperature activity profiles of the CMCase and the Avicelase both showed a shift against one another. This phenomenon may be attributed to the presence of two separate catalytic domains with presumably different properties. With both substrates, maximal activity was observed between $\mathrm{pH} 5$ and 6 . At lower $\mathrm{pH}$ values, the CMCase activity declined rapidly, whereas the Avicelase activity at $\mathrm{pH} 4.0$ was still $50 \%$ of the maximum. At $\mathrm{pH} 8.0$, the purified enzyme displayed $70 \%$ of the maximal CMCase 


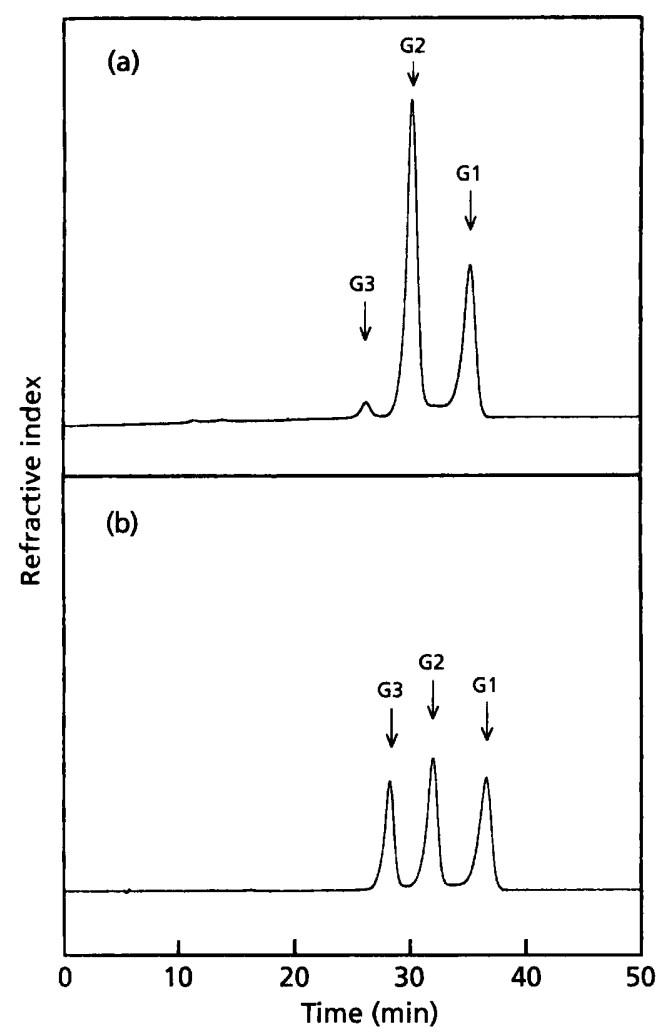

Fig. 6. HPLC analysis of degradation products released from Avicel by purified CelA (a) and CelA' (b) from ' $A$. thermophilum'. A standard reaction mixture containing a $1 \%$ $(\mathrm{w} / \mathrm{v})$ suspension of Avicel was incubated for $20 \mathrm{~h}$ at $72^{\circ} \mathrm{C}$ with purified CelA and CelA', respectively. G1, glucose; G2, cellobiose; G3, cellotriose.

activity but only $30 \%$ of the maximal Avicelase activity. A 'temperature optimum' of $85^{\circ} \mathrm{C}$ was determined in 60 min assays for Avicelase activity. At this temperature, the substrate was degraded at a constant rate for approximately $4 \mathrm{~h}$. Maximum $\mathrm{CMC}$ hydrolysis rates were measured between 95 and $100{ }^{\circ} \mathrm{C}$. However, at these temperatures the enzyme was rapidly inactivated showing a half-life of only $40 \mathrm{~min}$.

The relative rates of hydrolysis of a variety of substrates are summarized in Table 3 . In accordance with the identification of CelA as an endo-exo-cellulase fusion protein by sequence analysis, the purified enzyme displayed activity towards commonly used endoglucanase substrates such as CMC and $\beta$-glucan as well as towards the microcrystalline exoglucanase substrate Avicel. Like many other endoglucanases, CelA shows much higher activity towards the mixed-linkage substrate $\beta$-glucan than towards the soluble cellulose derivative CMC. Hydrolysis of xylan could also be detected, although the catalytic efficiency was low compared with that of typical xylanases. Remarkably, removal of the $\mathrm{C}$-terminal half of the enzyme as in the purified derivative CelA' leads to a significant reduction of the activity towards the microcrystalline substrate Avicel.
The products formed during hydrolysis of Avicel and cellodextrins were investigated by HPLC. The results of a kinetic analysis may be summarized as follows: (i) cellotetraose (G4), cellotriose (G3) and cellobiose (G2) were identified after short incubations $(2.5-5.0 \mathrm{~min})$ of Avicel and larger cellodextrins; (ii) G4 was rapidly cleaved into G3, G2 and glucose (G1); (iii) G3 was hydrolysed into G2 and G1 at a lower rate; (iv) after prolonged incubations $(20 \mathrm{~h}), \mathrm{G} 2, \mathrm{G} 1$ and minor amounts of G3 were detected as end-products formed by CelA action on Avicel and larger cellodextrins (Fig. 6a). The same products were released from Avicel by the truncated derivative CelA', but in a different ratio (Fig. 6b). Compared with full-length CelA, the relative amount of G3 was enhanced, whereas the formation of G2 was significantly reduced.

\section{DISCUSSION}

The multidomain cellulase CelA from ' $A$. thermophilum' described in this report is the first bifunctional cellulolytic enzyme which has been isolated from its native host, an extreme thermophile. For Ca. saccharolyticus (formerly named 'Caldocellum saccharolyticum'), several cel genes encoding bifunctional cellulolytic and/or hemicellulolytic enzymes have been described (Saul et al., 1990; Gibbs et al., 1992; Morris et al., 1995; Te'o et al., 1995). However, purification of the encoded large gene products has not been reported from either the heterologous host or the authentic organism. CelJ, the only known $\mathrm{Cl}$. thermocellum cellulase containing two catalytic domains on one polypeptide chain, could not be isolated in an intact form because of strong proteolytic processing in an E. coli recombinant (Ahsan et al., 1996). CelA has been identified as the major cellulolytic enzyme produced by ' $A$. thermophilum'. Despite its complex architecture and concomitant large size, the enzyme does not suffer from severe proteolysis in this microorganism. Presumably, CelA is protected against proteases of its authentic host by glycosylation. The enzyme contains three Pro-Thr-Ser linker regions (Fig. 4). Such sequence elements have been identified as sites of glycosylation in bacterial cellulolytic enzymes (Langsford et al., 1987; Ong et al., 1994). Accordingly, dense glycoprotein staining after SDS-PAGE has provided preliminary evidence for glycosylation of CelA from 'A. thermophilum'. Upon expression in an E. coli recombinant, proteolytic degradation rendered the isolation of the full-length gene product impossible. This may result from a deficiency in glycosylation (Sandercock et al., 1994; Herrmann et al., 1996) or from enhanced sensitivity to the proteolytic enzymes produced by the heterologous host.

Purified CelA is able to degrade the microcrystalline cellulose substrate Avicel. Remarkably, this Avicelase activity is significantly higher than that reported for fungal and bacterial cellobiohydrolases (Tomme et al., 1988; Bronnenmeier et al., 1991; Kruus et al., 1995). The activity towards the cellulosic substrate is of the same 
order of magnitude as that observed for synergistic admixtures of endoglucanase CelZ (Avicelase I) and exoglucanase CelY (Avicelase II) of Cl. stercorarium, provided the molecular masses of the two individual enzymes and that of the large bifunctional enzyme are taken into account (Riedel et al., 1997). The combined action of Avicelase I and II produces predominantly cellobiose and minor amounts of cellotriose and glucose as end-products of Avicel hydrolysis (Riedel et al., 1997). The same pattern of reaction products is found after prolonged incubations of Avicel with purified CelA enzyme (Fig. 6). Actually, CelA from the extreme thermophile 'A. thermophilum' can be regarded as a naturally occurring fusion protein of the two enzymes effecting cellulose hydrolysis in the less thermophilic organism $\mathrm{Cl}$. stercorarium. The different temperature and $\mathrm{pH}$ activity profiles determined for CelA with the substrates $\mathrm{CMC}$ and Avicel provided further evidence for a bifunctional organization of the large cellulolytic enzyme (Fig. 5). Finally, molecular cloning and sequence analysis of the CelA-encoding gene confirmed the above hypothesis. Homology analysis revealed a multidomain structure composed of two distinct catalytic domains from different glycosyl hydrolase families separated by binding domains and linker regions (Fig. 4). On the primary structure level, the $\mathrm{N}$-terminal family 9 catalytic domain of CelA is highly similar $(70.4 \%$ identity) to the catalytic region of the CelZ endoglucanase (Jauris et al., $1990)$ and the C-terminal family 48 domain shows $69 \cdot 2 \%$ sequence identity to the catalytic domain of the CelY exoglucanase (Bronnenmeier et al., 1997). The enzyme most closely related to CelA of ' $A$. thermophilum' is CelA of Ca. saccharolyticus (Te'o et al., 1995). Both proteins share a similar organization and an extremely high degree of sequence identity $196 \%$ for the $\mathrm{N}$-terminal domain, $94 \%$ for the binding domains and $97 \%$ for the C-terminal domain).

Identification of the $\mathrm{N}$-terminal CelA region as an endoglucanase domain was confirmed by the isolation of a truncated CelA derivative $\left(\mathrm{CelA}^{\prime}\right)$. The $90 \mathrm{kDa}$ CelA' is supposed to contain the glycosyl hydrolase family 9 catalytic domain joined to domains $\mathrm{C}^{\prime}$ and $\mathrm{C}$, which are homologous to family III cellulose-binding domains. The substrate specificity and the degradation pattern of this $\mathrm{N}$-terminal part of the CelA cellulase are comparable to those of other family 9 cellulases. The activity towards Avicel is of the same order of magnitude as that reported for $\mathrm{CelZ}$ of $\mathrm{Cl}$. stercorarium (Bronnenmeier \& Staudenbauer, 1990). However, the Avicelase activity of full-length CelA is significantly higher. Since the cellulose-binding capacity of the intact enzyme is maintained in the truncated derivative, an ability to degrade microcrystalline cellulose may be ascribed to the C-terminal catalytic domain. Accordingly, an enhanced amount of cellobiose has been detected in Avicel hydrolysates of full-length CelA (Fig. 6). This is in line with the identification of the Cterminal domain as a member of glycosyl hydrolase family 48 which contains exclusively bacterial exoglucanases. The enhanced Avicelase activity of CelA presumably results from intramolecular synergism between the endoglucanase and exoglucanase domains.

\section{ACKNOWLEDGEMENTS}

The authors are grateful to F. Lottspeich (MPI Martinsried) for $\mathrm{N}$-terminal protein sequence analysis. We also wish to thank L. Richter and W. Ludwig (TU München) for advice in using asymmetric PCR prior to publication. The work was supported by grants from the Deutsche Forschungsgemeinschaft ( $\mathrm{Br} 1472 / 2)$ and from the Volkswagen-Stiftung to K.B. V.Z. thanks the Deutsche Forschungsgemeinschaft for a travel grant.

\section{REFERENCES}

Ahsan, M. M., Kimura, T., Karita, S., Sakka, K. \& Ohmiya, K. (1996). Cloning, DNA sequencing, and expression of the gene encoding Clostridium thermocellum cellulase CelJ, the largest catalytic component of the cellulosome. J Bacteriol 178, 5732-5740.

Béguin, P. \& Aubert, J. P. (1994). The biological degradation of cellulose. FEMS Microbiol Rev 13, 25-58.

Bronnenmeier, K. \& Staudenbauer, W. L. (1990). Cellulose hydrolysis by a highly thermostable endo-1,4- $\beta$-glucanase (Avicelase I) from Clostridium stercorarium. Enzyme Microb Technol 12, 431-436.

Bronnenmeier, K., Rücknagel, K. P. \& Staudenbauer, W. L. (1991). Purification and properties of a novel type of exo-1,4- $\beta$-glucanase (Avicelase II) from the cellulolytic thermophile Clostridium stercorarium. Eur J Biochem 200, 379-385.

Bronnenmeier, K., Kundt, K., Riedel, K., Schwarz, W. H. \& Staudenbauer, W. L. (1997). Structure of the Clostridium stercorarium gene celY encoding the exo-1,4- $\beta$-glucanase Avicelase II. Microbiology 143, 891-898.

Flint, H. J., Martin, J., McPherson, C. A., Daniel, A. S. \& Zhang, J.-X. (1993). A bifunctional enzyme, with separate xylanase and $\beta(1,3-1,4)$-glucanase domains, encoded by the $x y n D$ gene of Ruminococcus flavefaciens. J Bacteriol 175, 2943-2951.

Gibbs, M. D., Saul, D. J., Luthi, E. \& Bergquist, P. L. (1992). The $\beta$-mannanase from Caldocellum saccharolyticum is part of a multidomain enzyme. Appl Environ Microbiol 58, 3864-3867.

Hall, J., Black, G. W., Ferreira, L. M., Millward-Sadler, S. J., Ali, B. R., Hazlewood, G. P. \& Gilbert, H. J. (1995). The non-catalytic cellulose-binding domain of a novel cellulase from Pseudomonas fluorescens subsp. cellulosa is important for the efficient hydrolysis of Avicel. Biochem J 309, 749-756.

Hanahan, D. (1983). Studies on transformation of Escherichia coli with plasmids. J Mol Biol 16, 557-580.

Hazlewood, G. P., Devidson, K., Laurie, J. I., Huskisson, N. S. \& Gilbert, H. J. (1993). Gene sequence and properties of CelI, a family E endoglucanase from Clostridium thermocellum. $J$ Gen Microbiol 139, 307-316.

Herrmann, J. L., O'Gaora, P., Gallagher, A., Thole, J. E. R. \& Young, D. B. (1996). Bacterial glycoproteins: a link between glycosylation and proteolytic cleavage of a $19 \mathrm{kDa}$ antigen from Mycobacterium tuberculosis. EMBO J 15, 3547-3554.

Jauris, S., Rücknagel, K. P., Schwarz, W. H., Kratzsch, P., Bronnenmeier, K. \& Staudenbauer, W. L. (1990). Sequence analysis of the Clostridium stercorarium celZ gene encoding a thermostable cellulase (Avicelase I) : identification of catalytic and cellulose-binding domains. Mol Gen Genet 223, 258-267. 
Laemmli, U. K. (1970). Cleavage of structural proteins during the assembly of the head of bacteriophage T4. Nature 277, 680-685. Langsford, M. L., Gilkes, N. R., Singh, B., Moser, B., Miller, R. C., Warren, R. A. J. \& Kilburn, D. G. (1987). Glycosylation of bacterial cellulases prevents proteolytic cleavage between functional domains. FEBS Lett 225, 163-167.

Kruus, K., Wang, W. K., Ching, J. \& Wu, J. H. D. (1995). Exoglucanase activities of the recombinant Clostridium thermocellum CelS, a major cellulosome component. J Bacteriol 177, 1641-1644.

Montgomery, L. \& Fu, Y.-K. (1988). Detection of cellulose-binding proteins in electrophoresis gels by filter paper affinity blotting. Anal Biochem 174, 204-208.

Morris, D. D., Reeves, R. A., Gibbs, M. D., Saul, D. J. \& Bergquist, P. L. (1995). Correction of the $\beta$-mannanase domain of the $c e l C$ pseudogene from Caldocellulosiruptor saccharolyticus and activity of the gene product on kraft pulp. Appl Environ Microbiol 61, 2262-2269.

Ong, E., Kilburn, D. G., Miller, R. C. \& Warren, R. A. J. (1994). Streptomyces lividans glycosylates the linker region of a $\beta-1,4-$ glycanase from Cellulomonas fimi. J Bacteriol 176, 999-1008.

Rainey, F. A., Ward, N. L., Morgan, H. W., Toalster, R. \& Stackebrandt, E. (1993). Phylogenetic analysis of anaerobic thermophilic bacteria: aid for their reclassification. $J$ Bacteriol $175,4772-4779$.

Rainey, F. A., Donnison, A. M., Janssen, P. H., Saul, D., Rodrigo, A., Bergquist, P. L., Daniel, R. M., Stackebrandt, E. \& Morgan, H. W. (1994). Description of Caldicellulosiruptor saccharolyticus gen. nov., spec. nov.: an obligately anaerobic, extremely thermophilic, cellulolytic bacterium. FEMS Microbiol Lett 120, 263-266.

Riedel, K., Ritter, J. \& Bronnenmeier, K. (1997). Synergistic interaction of the Clostridium stercorarium cellulases Avicelase I (CelZ) and Avicelase II (CelY) in the degradation of microcrystalline cellulose. FEMS Microbiol Lett 147, 239-243.

Sakamoto, R., Arai, M. \& Murao, S. (1984). Enzymatic properties of hydrocellulase from Aspergillus aculeatus. J Ferment Technol 62, 561-567.

Sambrook, J., Fritsch, E. F. \& Maniatis, T. (1989). Molecular Cloning: a Laboratory Manual, 2nd edn. Cold Spring Harbor, NY : Cold Spring Harbor Laboratory.

Sandercock, L. E., MacLeod, A. M., Ong, E. \& Warren, R. A. J. (1994). Non-S-layer glycoproteins in eubacteria. FEMS Microbiol Lett 118, 1-8.
Saul, D. J., Williams, L. C., Grayling, R. A., Chamley, L. W., Love, D. R. \& Bergquist, P. L. (1990). celB, a gene coding for a bifunctional cellulase from the extreme thermophile 'Caldocellum saccharolyticum'. Appl Environ Microbiol 56, 3117-3124.

Schwarz, W. H., Bronnenmeier, K., Gräbnitz, F. \& Staudenbauer, W. L. (1987). Activity staining of cellulases in polyacrylamide gels containing mixed linkage $\beta$-glucans. Anal Biochem 164, 72-77.

Sedmak, J. J. \& Grossberg, S. E. (1977). A rapid, sensitive assay for protein using Coomassie brilliant blue G250. Anal Biochem 79, 544-552.

Svetlichnyi, V. A., Svetlichnaya, T. P., Chernykh, N. A. \& Zavarzin, G. A. (1990). Anaerocellum thermophilum gen. nov. sp. nov.: an extremely thermophilic cellulolytic eubacterium isolated from hot springs in the valley of geysers. Microbiology (English translation of Mikrobiologiya) 59, 598-603.

Te'o, V. S. J., Saul, D. J. \& Bergquist, P. L. (1995). celA, another gene coding for a multidomain cellulase from the extreme thermophile Caldocellum saccharolyticum. Appl Microbiol Biotechnol 43, 291-296.

Tomme, P., Van Tilbeurgh, H., Pettersson, G., Van Damme, J., Vandekerckhove, J., Knowles, J., Teeri, T. \& Claeyssens, M. (1988). Studies of the cellulolytic system of Trichoderma reesei QM 9414. Eur J Biochem 170, 575-581.

Warren, R. A. J. (1996). Microbial hydrolysis of polysaccharides. Annu Rev Microbiol 50, 183-212.

Weimer, P. J., Wagner, W., Knowlton, S. \& Ng, T. K. (1984). Thermophilic anaerobic bacteria which ferment hemicellulose: characterization of organisms and identification of plasmids. Arch Microbiol 138, 31-36.

Wood, T. M. \& Bhat, K. M. (1988). Methods for measuring cellulase activities. Methods Enzymol 160, 87-112.

Yanisch-Perron, C., Vieira, J. \& Messing, J. (1985). Improved M13 phage cloning vectors and host strains: nucleotide sequences of the M13mp18 and pUC19 vectors. Gene 33, 103-119.

Zhang, J.-X. \& Flint, H. J. (1992). A bifunctional xylanase encoded by the $x y n A$ gene of the rumen cellulolytic bacterium Ruminococcus flavefaciens 17 comprises two dissimilar domains linked by an asparagine/glutamine-rich sequence. Mol Microbiol 6, 1013-1023.

Received 7 August 1997; revised 3 October 1997; accepted 17 October 1997. 